\title{
ANALISIS RASIO PROFITABILITAS PADA PT. BANK PERKREDITAN RAKYAT LUGAS DANA MANDIRI PADANG
}

\author{
Dwita Melia Putri, Doni Marlius \\ Akademi Keuangan dan Perbankan "Pembangunan" \\ Dwitaamelia2345@gmail.com
}

\begin{abstract}
The purpose of this study was to find out how the profitability rasio PT. BPR Lugas Dana Mandiri Padang. The research method used is the method of data analysis qualitative and quantitative. The tipe of data used is secondary data obtained from Financial Services Authority's Report and rural bank (BPR) publication reports for thr period 2017 - 2019. The results of this study indicate that the bank ROA level is still in an unhealthy position. ROE level also shows bank in unhealthy condition in generating net income, in the BOPO position has decreased but according to BI BOPO standards are still in the good category. While the bank NPM level has increased, which means the bank is said to be well at generating net income.
\end{abstract}

Keywords : Profitability, ROA, ROE, and NPM

\section{PENDAHULUAN}

Perkembangan dunia perbankan di Indonesia saat ini semakin kompetitif yang mana menuntut setiap perbankan untuk dapat mengolah dan membuat administrasi perbankan menjadi lebih ahli.

Menurut(Kasmir, 2014) Bank adalah badan usaha yang menghimpun dana dari masyarakat dalam bentuk simpanan dan menyalurkan kembali ke masyarakat dalam bentuk kredit atau bentuk-bentuk lainnya dalam rangka meningkatkan taraf hidup rakyat banyak. Menurut jenisnya bank terdiri dari Bank Umum dan Bank Perkreditan Rakyat (BPR).Bank Umum adalah bank yang mengadakan kegiatan usaha secara konvensional dan atau prinsip syariah yang kegiatannya memberikan jasa dalam lalu lintas pembayaran.Bank Perkreditan Rakyat (BPR) yaitu bank yang mengadakan kegiatan usaha secara konvensional dan atau prinsip syariah yang kegiatannya tidak memberikan jasa lalu lintas pembayaran.

Profitabilitas adalah rasio untuk menilai kemampuan perusahaan dalam mencari keuntungan.Rasio Profitabilitas merupakan perbandingan untuk mengetahui kemampuan perusahaan untuk mendapatkan laba dari pendapatan terkait penjualan, asset dan ekuitas berdasarkan dasar pengukuran tertentu.

Laporan Keuangan adalah hasil akhir dari proses akuntansi, yang terdiri dari dua laporan utama yaitu neraca dan laporan perhitungan laba rugi dan berupa laporan yang sifatnya sebagai pelengkap seperti laporan laba yang ditahan serta 
laporan sumber dan penggunaan dana atau laporan perubahan posisi keuangan (Fernos, 2017).

Berdasarkan pernyataan tersebut profitabilitas pada bank dapat diukur dengan beberapa ratio-ratio keuangan yaitu :Return on Asset, Return on Equity, Biaya Operasional (BOPO), dan Net Profit Margin. Return on asset juga disebut sebagai rentabilitas ekonomis merupakan ukuran kemampuan perusahaan dengan menghasilkan laba dengan semua aktiva yang dimiliki oleh perusahaan. Dalam hal ini laba yang dihasilkan adalah laba sebelum bunga dan pajak.Rasio ini menunjukkan tingkat efisiensi pengelolaan aktiva yanag dilakukan oleh perusahaan. Semakin besar ROA maka semakin besar tingkat keuntungan dan semakin baik posisi perusahaan dari segi penggunaan aktiva(Sutrisno, 2014) .

Return on Equity adalah rasio yang memperlihatkan sejauh manakah perusahaan mengelola modal sendiri secara efektif, mengukur tingkat keuntungan dari dari investasi yang telah dilakukan pemilik modal modal sendiri atau pemegang saham perusahaan. Semakin tinggi rasio ini semakin tinggi tinggi keuntungan investor karena semakin efisien modal yang ditanamkan.Biaya Operasional (BOPO) adalah perbandingan antara biaya operasional dan pendapatan operasional.Rasio biaya operasional digunakan untuk mengukur tingkat efisiensi dan kemampuan bank dalam melakukan kegiatan operasinya.Rasio ini membandingkan antara keuntungan bersih setelah pajak terhadap penjualan bersih.Agar BPR tersebut bisa tetap beroperasi maka BPR perlu memperhatikan laba yang diperolehnya, maka diperlukan analisis rasio profitabilitas.

PT. BPR Lugas Dana Mandiri salah satu bank yang ada di kota Padang, tepatnya terletak di J1 Raya Indarung Km 10 No. 10 Padang. BPR ini harus memperhatikan tingkat profitabilitas yang dimilikinya agar dapat mencapai suatu keuntungan yang lebih dimasa mendatang. Salah satu indicator yang dipakai untuk melihat keberhasilan atau kegagalan BPR dalam mencapai tujuan tersebut yaitu laporan keuangan kinerja keuangan bank yang telah dicapai.

\section{Tabel 1}

Perbandingan Rasio Profitabilitas PT. BPR Lugas Dana Mandiri Padang Tahun 2017 - 2019

(Ribuan Rupiah)

\begin{tabular}{|l|l|l|l|c|}
\hline \multicolumn{1}{|c|}{ Rasio } & \multicolumn{1}{|c|}{$\mathbf{2 0 1 7}$} & $\mathbf{2 0 1 8}$ & $\mathbf{2 0 1 9}$ & $\begin{array}{c}\text { Tingkat } \\
\text { Kesehatan BPR }\end{array}$ \\
\hline Return On Assets & $1,71 \%$ & $1,60 \%$ & $(2,06 \%)$ & $>1,22 \%$ \\
\hline Raturn On Equity & $02,52 \%$ & $02,53 \%$ & $03,96 \%$ & $>18 \%$ \\
\hline Biaya Operasional & $10,19 \%$ & $04,95 \%$ & $02,07 \%$ & $\underline{\leq 93,52 \%}$ \\
\hline Net Profit Margin & $114,35 \%$ & $69,82 \%$ & $72,08 \%$ & $\geq 5 \%$ \\
\hline
\end{tabular}

Sumber: Data Olahan

Berdasarkan tabel diatas secara umum dapat dilihat bahwa laporan keuangan PT. BPR Lugas Dana Mandiri Padang pada bulan Desember tahun 2017-2018 mengalami penurunan, sedangkan pada bulan Desember 2018Desember 2019 mengalami kenaikan beberapa persen.Dimana dapat dilihat ROA pada bulan Desember 2017-Desember 2018 mengalami penurunan, sedangkan pada bulan Desember 2018-Desember 2019 mengalami kenaikan beberapa 
persen. ROE pada bulan Desember 2017-Desember 2019 mengalami kenaikan sampai bebebrapa persen. BOPO pada bulan Desember 2017-Desember 2019 mengalami penurunan, tetapi menurut standar BI BOPO termasuk kategori baik. NPM pada bulan Desember 2017-Desember 2018 mengalami penurunan, sedangkan pada bulan Desember 2018-Desember 2019 mengalami kenaikan dibandingkan dengan tahun sebelumnya.

Berdasarkan masalah diatas, maka penulis tertarik untuk melakukan penelitian dengan judul "Analisis Rasio ProfitabilitasPT. Bank Perkreditan Rakyat Lugas Dana Mandiri Padang”. Berdasarkan uraian tersebut, maka tujuan penelitian ini yaitu untuk mengetahui bagaimana rasio profitabilitas yang diukur dari Return On Asset (ROA), Return On Equity (ROE), Biaya Operasional (BOPO), dan Net Profit Margin (NPM) yang ada pada PT. Bank Perkreditan Rakyat Lugas Dana Mandiri Padang bulan Desember 2017 - Desember 2019. Rumusan Masalah diatas yaitu berdasarkan tingkat profitabilitas pada PT. BPR Lugas Dana Mandiri Padang periode Desember 2017, Desember 2018, dan Desember 2019.

\section{LANDASAN TEORI Pengertian Bank}

Menurut (Kasmir, 2014)"Bank adalah suatu badan usaha yang bertugas menghimpun dana dari masyarakat dalam bentuk simpanan (deposito, tabungan, giro) dan menyalurkan kepada masyarakat dalam bentuk kredit dan atau bentukbentuk lainnya dalam rangka meningkatkan taraf hidup rakyat banyak.

Menurut Prasajaya, (2013) Bank merupakan lembaga keuangan, yang berperan dalam berkontribusi terhadap pembangunan ekonomi pada suatu Negara. Dari pengertiaan sebelumnya maka dapat disimpulkan pengertian bank adalah suatu badan keuangan yang dibawah naungan Undang-Undang suatu Negara yang berkekuatan hukum, sehingga pihak bank diwajibkan mematuhi dan mengikuti peraturan yang telah ditetapkan.

\section{Pengertian BPR}

Menurut (Kasmir, 2014) bahwa BPR adalah bank yang melaksanakan kegiatan usaha secara konvensional atau berdasarkan prinsip syariah dalam kegiatannya tidak memberikan jasa dalam lalu lintas pembayaran.

\section{Asas, Tujuan, Fungsi dan Sasaran Bank Perkreditan Rakyat}

BPR berasakan demokrasi ekonomi dengan menggunakan prinsip kehati hatian. Demokasi ekonomi adalah suatu ssistem ekonomi Indonesia yang dijalankan sesuai dengan pasal 33 UUD 1945 yang memiliki 8 ciri positif sebagai pendukung dan 3 ciri negatif yang harus dihindari (free fight liberalism, etatisme, dan monopoli).

Tujuan BPR adalah menunjang pelaksanaan pembangunan nasional dalam rangka meningkatkan pemerataan, pertumbuhan ekonomi, dan stabilitas nasional ke arah peningkatan kesejahteraan rakyat banyak. Fungsi BPR sendiri sudah sangat jelas yaitu sebagai badan usaha yang bertugas menghimpun dana dari masyarakat dalam bentuk simpanan (depositi, tabungan, giro) dan menyalurkan dana kepada masyarakat dalam bentuk kredit investasi, kredit modal kerja dan kredit perdagangan. 
Sasaran BPR adalah memenuhi kebutuhan para petani, peternak, nelayan, pedagang, pengusaha kecil, pegawai dan pensiunan, karena sasaran ini belum terjangkau oleh bank umum dan untuk lebih mewujudkan pemerataan layanan perbankan, pemerataan kesempatan berusaha, pemerataan pendapatan, agar mereka tidak jatuh ketangan para petugas uang rentenir.

\section{Pengertian laporan Keuangan}

(Fernos, 2017)Laporan keuangan (financial statement) merupakan suatu gambaran dari suatu perusahaan pada waktu tertentu biasanya satu periode akuntansi dan memberikan gambaran tentang kondisi keuangan yang dicapai perusahaan pada waktu tertentu. Jenis - jenis laporan keuangan yang dimaksud adalah sebagai berikut:

\section{a. Neraca}

Neraca merupakan laporan keuangan yang menunjukkan posisi keuangan bank pada tanggal tertentu.Posisi keuangna yang dimaksud adalah aktiva atau pasiva suatu bank.

b. Laporan Komitmen dan Kontijensi

Laporan Komitmen dan Kontijensi merupakan suatu ikatan atau kontrak yang berupa janji yang tidak dapat dibatalkan secara sepihak (irrevocable) dan harus dilaksanakan sesuai dengan kesepakatan bersama.

c. Laporan Laba Rugi

Laporan Laba Rugi merupakan bagian dari laporankeuangan suatu perusahaan yang dihasilkan pada suatu periode akuntansi yang menjabarkan unsur-unsur pendapatan dan beban perusahaan sehingga menghasilkan suatu laba bersih.

d. Laporan Arus Kas

Merupakan bagian dari laporan keuangan suatu perusahaan yang dihasilkan pada suatu periode akuntansi yang menunjukkan aliran masuk dan keluar uang perusahaan.

e. Catatan atau Laporan Kuangan

Merupakan catatan tambahan dan informasi yang ditambahkan ke akhir laporan keuangan untuk memberikan tambahan informasi kepada pembaca dengan informasi lebih lanjut.

\section{Pengertian Profitabilitas}

Dalam beroperasi untuk menghasilkan laba tersebut perusahaan menggunakan sumber dana baik sumber dana internal yakni dari modal pemilik dan laba ditahan maupun dari eksternal yakni sumber dana yang berasal dari pinjaman pihak lain (Sutrisno, 2014).

Kemampuan perusahaan dalam menghasilkan laba dengan semua aset yang dipunyai disebut sebagai Return On Assets(ROA), sedangkan kemampuan perusahaan dalam menghasilkan laba dengan modal sendiri disebut sebagai return on equity (ROE). Rasio BOPO digunakan untuk mengukur perbandingan antara biaya operasional yang ditanggung bank apabila dibandingkan dengan pendapatan operasional. Profitabilitas bisa juga diukur dengan net profit margin (NPM) yakni kemampuan menghasilkan laba dengan hasil penjualan penghasilan. 


\section{METODE PENELITIAN}

Dalam pengumpulan data untuk melakukan penelitian ini digunakan metode sebagai berikut :

1. Metode pengumpulan data

a. Studi lapangan (Field Research)

Peninjauan langsung ke objek penelitian yang dipilih untuk meneliti hasil data primer. Penelitian langsung ke lapangan ini akan membantu penulis untuk melengkapi data yang diperlukan. Adapun cara riset lapangan ini adalah dengan mewawancarai pihak-pihak yang berkepentingan dalam kondisi ini perusahaan atau instansi yang terkait.

b. Studi perpustakaan (Library research)

Penelitian yang dapat dilakukan ke perpustakaan untuk membaca beberapa buku-buku ilmiah dan tulisan-tulisanyang berhubungan dengan pembahasan yang akan dilakukan.

2. Metode analisa data

Dalam menganalisis data, penulis akan menggunakan analisis data kualitatif dan kuantitatif. Dimana kualitatif memahami dan menjelaskan data yang diteliti selama penelitian berlangsung, sedangkan kuantitatif menganalisis perhitungan tingkat profitabilitas pada PT. BPR Lugas Dana Mandiri Padang.

\section{HASIL DAN PEMBAHASAN}

Berdasarkan data keuangan PT. BPR Jorong Kampung Tangah Cabang Padang yang telah diperoleh, selanjutnya dilakukan perhitungan rasio keuangan dengan 4 indikator. Berikut perhitungan rasio keuangan tersebut.

\section{Return On Asset (ROA)}

(Sari \& Marlius, 2008)Return On Assets menunjukan kemampuan suatu perusahaan menghasilkan laba dari aktiva yang dipergunakan. Semakin tinggi rasio ini merupakan efektifitas dalam menggunakan total aktiva dalam menghasilkan laba.Dalam kerangka penilaian kesehatan bank, BI akan memberikan score maksimal 100 (sehat) apabila bank memiliki ROA lebih dari 1,22\%. Berdasarkan data yang diperoleh Return On Assets BPR Lugas Dana Mandiri Padang bulan Desember 2017 sampai Desember 2019 ditunjukkan pada tabel dibawah ini.

Tabel 2

Perhitungan ROA PT. BPR Lugas Dana Mandiri Padang Bulan Desember 2017 - bulan Desember 2019 (Ribuan Rupiah)

\begin{tabular}{|l|l|l|l|}
\hline \multicolumn{1}{|c|}{ Komponen } & Des 2017 & Des 2018 & Des 2019 \\
\hline $\begin{array}{l}\text { Laba bersih sebelum } \\
\text { pajak }\end{array}$ & 171.006 & 173.153 & $(225.960)$ \\
\hline Total Aktiva & 9.997 .003 & 10.785 .318 & 10.988 .716 \\
\hline
\end{tabular}

Sumber :Data Olahan

Dengan Formula

ROA $=\frac{\text { Laba Sebelum Pajak }}{\text { Total Aktiva }} \times 100 \%$ 
Desember 2017

$\mathrm{ROA}=\frac{171.006}{9.997 .003} \times 100 \%=1,71 \% \%$

Artinya rasio ROA PT. BPR Lugas Dana Mandiri Padang pada bulan Desember 2017 nilai ROA sebesar 1,71\%, bulan Desember 2018 nilai ROA sebesar 1,60\%, dan bulan Desember 2019 nilai ROA sebesar (2,06\%). Jadi dari bulan Desember 2017 sampai bulan Desember 2018 mengalami penurunan, walaupun demikian kinerja PT. BPR Lugas Dana Mandiri Padang tetap baik karena nilai nya masih diatas rata - rata penilaian BI. Jika ROA semakin rendah bank tidak akan bisa beroperasi dengan efektif dan efisien dalam memanfaatkan asset yang dimilikinya dalam menghasilkan keuntungan.

2. Return On Equity (ROE)

(Afriyeni \& Fernos, 2018)Return On Assets menunjukkan dari modal sendiri untuk menghasilkan keuntungan bagi pemegang saham preferen dan saham biasa, semakin besar rasio ini maka akan semakin baik. Bahwa Return On Equity merupakan rasio yang mengukur kemampuan suatu perusahaan dalam menghasilkan laba bersih dari modal sendiri yang digunakan oleh perusahaan. Menurut standar BI ROE adalah lebih dari 12\% (baik). Berdasarkan data yang di peroleh Return On Equity BPR Lugas Dana Mandiri Padang selama bulan Desember 2017 sampai dengan Desember 2019 ditunjukkan pada tabel di bawah ini:

Tabel 3

Perhitungan ROE BPR Lugas Dana Mandiri Padang

Bulan Desember 2017 - Desember 2019

(Ribuan Rupiah)

\begin{tabular}{|l|l|l|l|}
\hline \multicolumn{1}{|c|}{ Komponen } & \multicolumn{1}{c|}{ Des 2017 } & \multicolumn{1}{c|}{ Des 2018 } & \multicolumn{1}{c|}{ Des 2019 } \\
\hline Laba besih setelah pajak & 151.058 & 152.104 & $(237.865)$ \\
\hline Modal sendiri & 6.000 .000 & 6.000 .000 & 6.000 .000 \\
\hline
\end{tabular}

Sumber: Data Olahan

Dengan Formula

$\mathrm{ROE}=\frac{\text { Laba Bersih Setelah Pajak }}{\text { Modal Sendiri }} \times 100 \%$

Desember 2017

$\mathrm{ROE}=\frac{151.058}{6.000 .000} \times 100 \%=2,52 \%$

Artinya rasio ROE BPR Lugas Dana Mandiri Padang pada bulan Desember 2017 nilai ROE sebesar 02,52\%, bulan Desember 2018 nilai ROE sebesar 02,53\%, dan bulan Desember 2019 nilai ROE sebesar 03,96\%, sehingga semakin besar rasio ini maka akan semakin baik kemampuan suatu perusahaan dalam menghasilkan laba bersih dari modal sendiri.

3. Biaya Operasional dan Pendapatan Operasional (BOPO)

(Afriyeni \& Fernos, 2018)Rasio BOPO digunakan untuk mengukur perbandingan antara biaya operasional yang ditanggung bank apabila dibandingkan dengan pendapatan operasional yang mampu dihasilkan.Semakin tinggi persentase BOPO menunjukkan biaya 
operasional yang terjadi melebihi pendapatan operasional yang mampu diperoleh oleh suatu bank. Menurut standar BI menetapkan rasio BOPO adalah di bawah 90\%, karena jika rasio BOPO melebihi 90\% hingga mendekati $100 \%$ maka bank tersebut dapat dikategorikan tidak efisien dalam menjalankan kegiatan operasionalnya. Berdasarkan data yang diperoleh biaya operasional (BOPO) BPR Lugas Dana Mandiri Padang selama bulan Desember 2017 sampai dengan bulan Desember 2019 dapat ditunjukkan pada tabel di bawah ini:

\section{Tabel 4}

Perhitungan Biaya Operasional BPR Lugas Dana Mandiri Padang Bulan Desember 2017 - Desember 2019 (Ribuan Rupiah)

\begin{tabular}{|l|l|l|l|}
\hline \multicolumn{1}{|c|}{ Komponen } & \multicolumn{1}{c|}{ Des 2017 } & \multicolumn{1}{c|}{ Des 2018 } & Des 2019 \\
\hline Total Beban Operasional & 13.466 & 10.784 & 6.823 \\
\hline $\begin{array}{l}\text { Total Pendapatan } \\
\text { Operasional }\end{array}$ & 132.092 & 217.858 & 330.001 \\
\hline
\end{tabular}

Sumber: Data Olahan

Dengan Formula

$\mathrm{BOPO}=\frac{\text { Total Beban Operasional }}{\text { Total Pendapatan Operasional }} \times 100 \%$

Desember 2017

$\mathrm{BOPO}=\frac{\text { Total Beban Operasional }}{\text { Total Pendapatan Operasional }} \times 100 \%$

$\mathrm{BOPO}=\frac{13.466}{132.092} \times 100 \%=10,19 \%$

Artinya rasio BOPO BPR Lugas Dana Mandiri Padang pada bulan Desember 2017 nilai BOPO sebesar 10,19\%, bulan Desember 2018 nilai BOPO sebesar 04,95\%, dan pada bulan Desember 2019 nilai BOPO sebesar 02,07\%. Semakin kecil semakin efisien bank tersebut mengendalikan biaya operasionalnya, maka keuntungan yang diperoleh bank akan semakin besar.

4. Net Profit Margin (NPM)

(Puspitasari, 2018)Net Profit Margin (NPM) merupakan rasio yang menghitung sejauh mana kemampuan perusahaan menghasilkan laba bersih pada tingkat penjualan tertentu.Rasio ini membandingkan antara keuntungan bersih setelah pajak terhadap penjualan bersih.Semakin tinggi berarti menunjukkan kemampuan perusahaan menghasilkan laba yang tinggi pada tingkat penjualan tertentu.Menurut standar BI NPM lebih dari 5\% (baik). Berdasarkan data yang diperoleh NET Profit Margin BPR Lugas Dana Mandiri Padang selama bulan Desember 2017 sampai bulan Desember 2019 ditunjukkan pada tabel dibawah ini: 
Tabel 5

Perhitungan NPM BPR Lugas Dana Mandiri Padang

Bulan Desember 2017 - Desember 2019

(Ribuan Rupiah)

\begin{tabular}{|l|l|l|l|}
\hline \multicolumn{1}{|c|}{ Komponen } & Des 2017 & Des 2018 & \multicolumn{1}{c|}{ Des 2019 } \\
\hline Laba bersih setelah pajak & 151.058 & 152.104 & $(237.865)$ \\
\hline $\begin{array}{l}\text { Total pendapatan } \\
\text { operasional }\end{array}$ & 132.092 & 217.858 & 330.001 \\
\hline
\end{tabular}

Sumber: Data Olahan

$\mathrm{NPM}=\frac{\text { Laba Bersih Setelah Pajak }}{\text { Total Pendapatan Operasional }} \times 100 \%$

Desember 2017

$\mathrm{NPM}=\frac{151.058}{132.092} \times 100 \%=114,35 \%$

Artinya rasio NPM BPR Lugas Dana Mandiri Padang pada bulan Desember 2017 nilai NPM sebesar 114,35\%, bulan Desember 2018 nilai NPM sebesar 69,82\%, dan pada bulan Desemeber 2019 nilai NPM sebesar 72,08\%. Jadi dari bulan Desember 2017 sampai bulan Desember 2018 mengalami penurunan,sehingga kemampuan bank menurun dalam menghasilkan laba bersihnya.

\section{SIMPULAN}

Berdasarkan hasil analisis pada bab sebelumnya, gambaran tingkat profitabilitas PT. BPR Lugas Dana Mandiri Padang bulan Desember 2017 Desember 2019 ditunjukkan pada tabel sebagai berikut:

Tabel 6

Perbandingan Rasio Profitabilitas PT. BPR Lugas Dana Mandiri Padang Bulan Desember 2017 - Desember 2019

(Ribuan Rupiah)

\begin{tabular}{|l|l|l|l|l|}
\hline \multicolumn{1}{|c|}{ Rasio } & \multicolumn{1}{|c|}{$\mathbf{2 0 1 7}$} & $\mathbf{2 0 1 8}$ & $\mathbf{2 0 1 9}$ & $\begin{array}{c}\text { Tingkat } \\
\text { Kesehatan BPR }\end{array}$ \\
\hline Return On Assets & $1,71 \%$ & $1,60 \%$ & $(2,06 \%)$ & $\geq 1,22 \%$ \\
\hline Raturn On Equity & $02,52 \%$ & $02,53 \%$ & $03,96 \%$ & $\underline{>18 \%}$ \\
\hline Biaya Operasional & $10,19 \%$ & $04,95 \%$ & $02,07 \%$ & $\leq 93,52 \%$ \\
\hline Net Profit Margin & $114,35 \%$ & $69,82 \%$ & $72,08 \%$ & $\underline{>5 \%}$ \\
\hline
\end{tabular}

Sumber: Data Olahan

1. Rasio ROA BPR Lugas Dana Mandiri Padang pada bulan Desember 2017 nilai ROA sebesar 1,71\%, bulan Desember 2018 nilai ROA sebesar 1,60\%, dan bulan Desember 2019 nilai ROA sebesar (2,06\%). Jadi dari bulan Desember 2017 sampai bulan Desember 2019 mengalami penurunan. Walaupun demikian kinerja BPR Lugas Dana Mandiri Padang tetap baik karena nilainya masih diatas rata - rata penilaian BI. Apabila ROA semakin rendah bank tidak akan bisa beroperasi dengan efektif dan efisien dalam memanfaatkan asset yang dimilikinya dalam menghasilkan keuntungan. 
2. Rasio ROE BPR Lugas Dana Mandiri Padang pada bulan Desember 2017 nilai ROE sebesar 02,52\%, bulan Desember 2018 nilai ROE sebesar 02,53\% dan bulan Desember 2019 nilai ROE sebesar $(03,96) \%$ mengalami penurunan atau dikatakan tidak baik karena menurut standar BI ROE lebih dari $12 \%$ itu artinya baik, sehingga kemampuan bank dalam menghasilkan laba bersih dari modalnya rendah.

3. Rasio BOPO BPR Lugas Dana Mandiri Padang pada bulan Desember 2017 nilai BOPO sebesar 10,19\%, bulan Desember 2018 nilai BOPO sebesar 04,95\% dan bulan Desember 2019 nilai BOPO sebesar 02,07\%. Semakin kecil BOPO semakin efisien bank tersebut mengendalikan biaya operasionalnya, maka keuntungan yang diperoleh bank akan semakin besar.

4. Rasio NPM Lugas Dana Mandiri Padang pada bulan Desember 2017 nilai NPM sebesar 114,35\% bulan Desember 2018 nilai NPM sebesar 69,82\% dan bulan Desember 2019 nilai NPM sebesar 72,08\%, jadi dari bulan Desember 2017 sampai bulan Desember 2018 mengalami penurunan. Sehingga kemampuan bank menurun dalam menghasilkan laba bersihnya.

\section{UCAPAN TERIMA KASIH}

Terimakasih penulis sampaikan kepada :

1. Allahumma fighfirlii wa liwaa lidhayya warham humaa kamma rabbayaa nii shokhiroon. Ayahandaku (Anwir) dan ibundaku tercinta (Asniati) yang telah mengasuh, membimbing, mendidik serta memberikan cinta kasih baik berupa moral, materi dan bahkan hidupnya, tak ada kata yang mampu mendefinisikan kedua orang terhebat ini. Semoga allah senantiasa memberikan kesehatan dan umur yang panjang bagi kedua orangtuaku jazakumullahu khairan katsira aamiin allahumma aamiin.

2. Ibu Afriyeni, SE, MM selaku direktur AKBP Padang yang telah memberikan fasilitas dan kemudahan kepada penulis sehingga studinya dapat berjalan dengan lancar.

3. Bapak Doni Marlius, SE.MM selaku ketua Prodi Akademi Keuangan dan Perbankan "Pembangunan" Padang sekaligus dosen pembimbing yang telah membantu dan membimbing penulis baik itu arahan, nasehat, dan motivasi yang membangunkan semangat penulis .

4. Bapak-bapak dan ibu-ibu dosen/staff pengajarAKBP-STIE "KBP” Padang, karyawan/i dan segenap civitas akademika yang telah membantu penulis selama menempuh pendidikan di kampus ini.

5. Terakhir, terima kasih juga kepada semua pihak yang telah membantu dalam penyelesaian Tugas Akhir ini yang tidak dapat disebutkan satu per satu. 


\section{DAFTAR PUSTAKA}

Afriyeni, A., \& Fernos, J. (2018). Analisis Faktor-Faktor Penentu Kinerja Profitabilitas Bank Perkreditan Rakyat (Bpr) Konvensional Di Sumatera Barat. Jurnal Benefita, 3(3), 325. https://doi.org/10.22216/jbe.v3i3.3623

Badria, M., \& Marlius, D. (2019). Analisis Rasio Likuiditas Pada PT. Bank Perkreditan Rakyat (BPR) Lengayang. https://doi.org/10.31219/osf.io/esvb7

Fernos, J. (2017). ANALISIS RASIO PROFITABILITAS UNTUK MENGUKUR KINERJA (Studi Kasus Pada PT. Bank Pembangunan Daerah Provinsi Sumatera Barat). Jurnal Pundi, 1(2), 14. https://doi.org/10.31575/jp.v1i2.25

Fitri, H. Y., \& Marlius, D. (2019). Analisis Rasio Likuiditas Pada PT. Bank Perkreditan Rakyat (BPR) Nagari Kasang. https://doi.org/10.31219/osf.io/bcs73

Handayani, M., \& Marlius, D. (2017). Analisis Tingkat Kesehatan PT. BPR Batang Kapas. https://doi.org/10.31227/osf.io/bq48z

Kasmir, D. (2014). Bank Dan Lembaga Keuangan Lainnya. Edisi Revisi 2014 PT Raja Grafindo Persada Jakarta.

Mustika, S., \& Marlius, D. (2019). Analisa Tingkat Kesehatan Keuangan PT. Bank Perkreditan Rakyat (BPR) Batang Palangki. https://doi.org/10.31219/osf.io/wupyh

Prasajaya, A. . Y. (2013). Amelia Showalter_SearchLove London 2013. E- Jurnal Akuntansi Universitas Udayana 4.1 (2013) 230-245, 1, 230-245. https://doi.org/10.1016/j.jemermed.2010.11.035

Purwanto, A. J. (2014). Pentingnya Mempelajari Teori Organisasi. Teori Organisasi, 1-51.

Puspitasari, R. (2018). Sebagai salah satu syarat untuk memperoleh gelar Ahli Madya pada Program Studi Keuangan dan Perbankan Sekola Tinggi Ilmu Ekonomi Kesatuan. July. https://doi.org/10.13140/RG.2.2.10882.99522

Sari, Y. P., \& Marlius, D. (2008). Analisis Rasio Profitabilitas Pada PT. Bank Negara Indonesia Syariah. Akademi Keuangan Dan Perbankan Padang, 21, 1-11. www.bnisyariah.co.id

Sinugan, M. (1997). Menejemen Dana Bank (p. 317). PT. Bumi Aksara, Jakarta.

Sutrisno. (2014). Pengaruh Profitabilitas Terhadap Kebijakan Dividen dan Nilai Perusahaan. 10(2), 32-48.

Tanjung, M. S. B. (n.d.). Penyelesaian kredit bermasalah pada pt. bank perkreditan rakyat (bpr) mitra danagung padang. 1-20. 